\title{
PENERAPAN MODEL EXPERIENTIAL LEARNING UNTUK MENINGKATKAN HASIL BELAJAR IPA TEMA PANAS DAN PERPINDAHANNYA DI SEKOLAH DASAR
}

\author{
IMPLEMENTATION OF EXPERIENTIAL LEARNING MODEL TO IMPROVE SCIENCE \\ LEARNING OUTCOMES IN HEAT AND DISPLACEMENT TOPIC AT THE ELEMENTARY \\ SCHOOL
}

\author{
Arum Haryanti*, Suhartono, Moh. Salimi \\ Program Studi Guru SD, Fakultas Keguruan dan Ilmu Pendidikan, Universitas Sebelas Maret. \\ Jalan Kepodang 67A Panjer Kebumen \\ *Email: haryantiarum6@gmail.com
}

Diterima: 10 Februari 2019. Disetujui: 04 Maret 2019. Dipublikasikan: 31 Maret 2019

\begin{abstract}
Abstrak: Penelitian ini dilakukan untuk menerapkan langkah model Experiential Learning, meningkatkan hasil belajar IPA pada tema Panas dan Perpindahannya, dan mengidentifikasi kendala penerapan model dan solusinya dalam pembelajaran. Penelitian ini merupakan penelitian tindakan kelas kolaboratif yang dilaksanakan dalam dua siklus, setiap siklus terdiri dari tahap perencanaan, pelaksanaan, observasi, dan refleksi. Subjek penelitian ini adalah guru dan peserta didik kelas V Sekolah Dasar Negeri 3 Waluyo tahun ajaran 2018/2019. Data yang dianalisis berupa data kualitatif yaitu penggunaan model Experiential Learning dan data kuantitatif yaitu hasil belajar Ilmu Pengetahuan Alam peserta didik. Hasil penelitian menunjukkan bahwa model Experiential Learning yang dilaksanakan dengan langkah-langkah Concrete Experience, Reflective Observation, Abstract Conceptualization, dan Active Experimentation dapat meningkatkan hasil belajar IPA pada tema Panas dan Perpindahannya di kelas V Sekolah Dasar Negeri 3 Waluyo tahun ajaran 2018/2019 yang dibuktikan dengan persentase ketuntasan hasil belajar pada siklus I sebesar 76,33 \% menjadi 92,63 \% pada siklus II. Kendala yang ditemui yaitu terdapat peserta didik yang kurang aktif menjawab pertanyaan, sulit memahami materi, malu mempresentasikan hasil diskusi, kurang fokus dalam pembelajaran, dan kesulitan menyampaikan pendapat dengan bahasa yang jelas. Solusi yang diterapkan yaitu memberikan penghargaan bagi peserta didik yang aktif, memberikan bimbingan dan pengawasan yang lebih, menunjuk semua anggota kelompok mempresentasikan hasil diskusi, dan membimbing peserta didik saat penyampaian pendapat.
\end{abstract}

Kata Kunci: Experiential Learning, IPA, panas dan perpidahannya

Abstract: This research was conducted to implement the Experiential Learning model in order to improve the learning outcomes of science on the theme of heat and displacement topic, and identify the obstacle of the application of models and its solutions. This study was a collaborative classroom action research conducted in two cycles. Each cycle consists of the stages of planning, implementation, observation, and reflection. The subjects of this study were teachers and students of fifth grade of Sekolah Dasar Waluyo 3 in the Academic Year 2018/2019. The data analyzed were in the form of qualitative data, namely the use of Experiential Learning models and quantitative data as the learning outcomes of Natural Sciences students. The results showed that the Experiential Learning model carried out with the steps of Concrete Experience, Reflective Observation, Abstract Conceptualization, and Active Experimentation could improve science learning outcomes on the theme of Heat and Displacement in the fifth grade of Sekolah Dasar Waluyo 3 in the Academic Year $2018 / 2019$ with the percentage of completeness of learning outcomes in the first cycle of $76.33 \%$ to $92.63 \%$ in cycle II. The obstacles encountered during the learning processes eere less active student in answering questions, difficulty in understanding the material, unconfident in presenting the results of the discussion, were lack of focus in learning, and difficulty in expressing opinions clearly. Solutions that were implemented are giving awards to the active students, providing more guidance and supervision, pointing out all group members presenting the results of the discussion, and guiding students when delivering opinions.

Keywords: experiential learning, natural sciences, heat and displacement

\section{PENDAHULUAN}

Ilmu Pengetahuan Alam (IPA) merupakan salah satu mata pelajaran pokok dalam kurikulum pendidikan Indonesia termasuk pada jenjang sekolah dasar [1]. Pembelajaran IPA di SD merupakan proses pembelajaran yang berdasarkan prinsip dan proses yang mengambangkan kemampuan berpikir kritis peserta didik. Mata pelajaran IPA di kelas V SD pada Kurikulum 2013 terintegrasi dengan mata pelajaran Bahasa Indonesia dan SBdP. Salah satu tujuan pembelajaran IPA yaitu memperoleh bekal 
pengetahuan, konsep, dan keterampilan IPA sebagai dasar untuk melanjutkan pendidikan ke SMP $[1,13]$

Berdasarkan observasi awal, diketahui bahwa pembelajaran yang dilakukan masih berpusat pada guru, belum mengembangkan kegiatan belajar dengan model maupun metode pembelajaran yang mendukung keterlibatan peserta didik, dan belum memanfaatkan lingkungan alam sekitar untuk membantu penerapan konsep-konsep IPA. Kondisi tersebut berdampak pada ketuntasan hasil belajar IPA pada Penilaian Tengah Semester (PTS) semester ganjil yang baru mencapai $48 \%$.

Dari uraian permasalahan tersebut, maka pembelajaran IPA yang dilakukan perlu diadakan perbaikan. Pembelajaran IPA akan lebih bermakna jika ditunjang dengan kegiatan pengalaman langsung seperti diskusi, pengamatan, serta penelitian sederhana [2]. Menurut Samatowa (2016) model belajar yang sesuai bagi anak Indonesia adalah belajar melalui pengalaman langsung (learning by doing) yang memanfaatkan alat maupun media belajar dari lingkungan peserta didik [12]. Selain itu, pembelajaran juga harus berjalan dalam atmosfer yang bersahabat, enyenangkan, dan memenuhi kebutuhan penting peserta didik dalam proses pembalajaran [8]. Salah satu model yang ditunjang dengan keterlibatan peserta didik dan pembelajaran yang menyenangkan adalah model Experiential Learning. Menurut Fathurrohman (2017), Experiential Learning merupakan model yang memusatkan pada peserta didik dan pengalamannya yang didasari oleh ungkapan the experience is the best teacher [4]. Makna dalam ungkapan tersebut yaitu pengalaman belajar yang dimiliki peserta didik dapat mengembangkan kemampuan, keterampilan, serta pola pikir baru yang lebih baik. Langkah model Experiential Learning yaitu Concrete Experience atau pengalaman nyata, Reflective Observation atau observasi refleksi, Abstract Conceptualization atau penyusunan konsep abstrak, dan Active Experimentation atau eksperimen aktif $[3,10]$.

Berdasarkan uraian di atas, peneliti melakukan penelitian dengan tujuan (1) mendeskripsikan langkah penggunaan model Experiential Learning untuk meningkatkan hasil belajar IPA pada tema Panas dan Perpindahannya, (2) meningkatkan hasil belajar IPA pada tema Panas dan Perpindahannya dengan penggunaan model Experiential Learning, serta (3) mendeskripsikan kendala dan solusi penggunaan model Experiential Learning dalam peningkatan hasil belajar IPA pada tema Panas dan Perpindahannya.

\section{METODE PENELITIAN}

penelitian tindakan kelas kolaboratif yang melibatkan peneliti dan guru kelas V SDN 3 Waluyo. Subjek dalam penelitian yaitu guru dan peserta didik kelas V yang berjumlah 27 peserta didik. Data pada penelitian ini meliputi data kualitatif berupa penerapan model Experiential Learning dalam pembelajaran dan data kuantitatif berupa hasil belajar peserta didik pada mata pelajaran IPA. Data pada penelitian ini bersumber dari guru dan peserta didik kelas $\mathrm{V}$ dengan teknik pengumpulan data menggunakan tes, observasi, dan wawancara. Uji validitas data menggunakan triangulasi teknik dan triangulasi sumber. Analisis data penelitian meliputi kegiatan reduksi data, penyajian data, dan penarikan kesimpulan.

Indikator kinerja pada penelitian ini yaitu pelaksanaan langkah pembelajaran dengan model Experiential Learning dan ketuntasan hasil belajar IPA dengan ketercapaian target $85 \%$. Prosedur dalam penelitian ini meliputi tahap perencanaan, pelaksanaan, pengamatan, dan refleksi.

\section{HASIL DAN PEMBAHASAN}

Penggunaan model Experiential Learning dalam pembelajaran IPA meliputi langkah-langkah: (1) Concrete Experience/pengalaman nyata, (2) Reflective Observation/observasi refleksi, (3) Abstract Conceptualization/penyusunan konsep abstrak, dan (4) Active Experimentation/eksperimen aktif. Langkahlangkah model yang digunakan peneliti dalam pembelajaran mengacu pada langkah-langkah yang dikemukakan oleh Kolb [3,6,7,9]. yang disimpulkan menjadi langkah yang telah disebutkan di atas.

Pembelajaran dengan pennggunaan model Experiential Learning diamati oleh observer berdasarkan lembar observasi terhadap guru dan peserta didik. Hasil observasi pada siklus I dan siklus ditampilkan pada Tabel I.

Tabel 1. Analisis Hasil Observasi Penggunaan Model Experiential Learning

\begin{tabular}{llll}
\hline \multirow{2}{*}{ Sumber Data } & \multicolumn{2}{l}{ Siklus } \\
\cline { 3 - 4 } & & I & II \\
\hline Guru & Persentase (\%) & 85,07 & 90,62 \\
\hline Peserta didik & Persentase (\%) & 84,38 & 90,28 \\
\hline
\end{tabular}

Berdasarkan tabel 1 di atas, dapat diambil kesimpulan bahwa proses pembelajaran pada siklus I dan siklus II mengalami kenaikan yang signifikan. Hasil observasi terhadap capaian guru pada siklus I yaitu $85,07 \%$ dan pada siklus II yaitu 90,62\%. Hasil observasi terhadap capaian peserta didik pada siklus I yaitu $84,38 \%$ dan pada siklus II yaitu $90,28 \%$.

Data hasil belajar peserta didik didapatkan dari hasil evaluasi setelah kegiatan belajar mengajar pada siklus I dan siklus II. Hasil evaluasi 
yang diperoleh peserta didik pada siklus I dan siklus II ditampilkan pada Tabel 2.

Berdasarkan tebel di atas, dapat diambil kesimpulan bahwa hasil belajar peserta didik mengalami peningkatan pada siklus II. Rata-rata ketuntasan hasil belajar pada siklus I sebesar 76,33 $\%$ dan siklus II sebesar 92,63\%. Ketuntasan hasil belajar pada siklus II telah mencapai indikator kinerja penelitian yang ditetapkan yaitu $85 \%$. Berdasarkan hasil evaluasi, dapat disimpulkan bahwa kesulitan sebagian peserta didik pada siklus I yaitu soal jenjang $\mathrm{C} 2, \mathrm{C} 4$, dan penulisan jawaban uraian secara lengkap. Kendala tersebut telah dapat diatasi pada siklus II. Namun, peserta didik masih terkecoh dengan opsi jawaban soal pilihan ganda pada jenjang kognitif aplikasi (C3).

Pada siklus I guru banyak mengalami kendala pada langkah Reflective Observation dan Abstract Conceptualization sedangkan pada siklus II kendala yang dialami guru yaitu pada pengelolaan kelas khususnya pengondisian peserta didik. Pada siklus I peserta didik juga banyak terkendala pada langkah Reflective Observation dan Abstract Conceptualization sedangkan pada siklus II kendala yang muncul hanya kesulitan saat menyampaikan pendapat menggunakan bahasa yang baku dan jelas.

Tabel 2. Analisis Hasil Belajar Peserta Didik Siklus I dan Siklus II

\begin{tabular}{|c|c|c|c|c|c|c|}
\hline \multirow[b]{2}{*}{ Aspek } & \multicolumn{3}{|c|}{ Siklus I } & \multicolumn{3}{|c|}{ Siklus II } \\
\hline & $\begin{array}{c}\text { Pertemuan } \\
1\end{array}$ & $\begin{array}{l}\text { Pertemuan } \\
2\end{array}$ & $\begin{array}{c}\text { Pertemuan } \\
3\end{array}$ & $\begin{array}{c}\text { Pertemuan } \\
1\end{array}$ & $\begin{array}{l}\text { Pertemuan } \\
\quad 2\end{array}$ & $\begin{array}{c}\text { Pertemuan } \\
3\end{array}$ \\
\hline Tuntas (\%) & 63 & 81 & 85 & 85 & 93 & 100 \\
\hline Belum Tuntas $(\%)$ & 37 & 19 & 15 & 15 & 7 & 0 \\
\hline Rata-rata (\%) & 73,89 & 78,70 & 82,22 & 82,40 & 87,59 & 90,93 \\
\hline
\end{tabular}

Pada langkah Concrete Experience, guru mengondisikan peserta didik untuk mengikuti pembelajaran dengan kegiatan apersepsi dan kegiatan diskusi besar terkait topik yang akan dibahas. Melalui tanya jawab tersebut, guru menggali pengetahuan awal peserta didik dengan pertanyaan pancingan yang memungkinkan peserta didik mengemukakan pengalamannya masingmasing. Llangkah ini menekankan pada ragam kejadian yang telah dialami individu dalam kehidupannya dan digali melalui apersepsi awal pembelajaran. Langkah pengalaman nyata ini telah dilakukan dengan baik oleh guru dan direspon oleh sebagian besar peserta didik sehingga mereka termotivasi untuk menjawab pertanyaan pancingan guru. Namun ada beberapa anak yang kurang aktif menjawab karena malu dan belum memahami maksud dari pertanyaan guru [9].

Tahap Reflective Observation dilakukan dengan kegiatan tanya jawab yang lebih mendalam, pembagian kelompok, dan kegiatan diskusi kelompok tentang panas dan perpindahannya. Hal ini sesuai dengan pendapat Rodliyah, Saraswati, \& Sa'adah [11], bahwa pengalaman konkret yang telah digali dari peserta didik akan direfleksikan secara individu untuk dipahami dan dipikirkan. Tanya jawab dilakukan dengan lebih detail dan mendalam berdasarkan pengalaman yang diungkapkan peserta didik sebelumnya. Melalui kegiatan tersebut, peserta didik ditekankan agar dapat menerapan pengetahuan awalnya pada konsep IPA yang akan diajarkan. Jika peserta didik telah paham tentang konsep IPA yang akan dipelajari, guru membimbing dan mendampingi peserta didik dalam melakukan diskusi kelompok untuk memastikan setiap individu aktif berpendapat di dalam kelompok.

Langkah Abstract Conceptualization merupakan kegiatan analisis latar belakang dan keterkaitan antara pengalaman yang diperoleh dengan prinsip dan konsep yang ada. Kegiatan peserta didik terfokus pada pencarian sumber belajar yang mendukung topik diskusi yang dibahas dalam kelompok dan kegiatan mengomunikasikan hasil diskusi kelompok di depan kelas. Sebagian besar peserta didik telah mampu mempresentasikan hasil diskusi, memberikan tanggapan, serta memperbaiki jawaban kelompok yang masih keliru dengan bimbingan guru.

Pada tahap Active Experimentation atau yang dikenal dengan tahap implementasi ini dilakukan dengan kegiatan percobaan sederhana oleh peserta didik tentang panas dan perpindahannya, mengerjakan LKS berdasarkan percobaan yang dilakukan, penyimpulan materi pembelajaran, serta pemberian soal evaluasi untuk menguji pemahaman peserta didik. Langkahlangkah yang dilakukan sesuai dengan pendapat Fathurrohman [4] bahwa setelah peserta didik melakukan aktivitas percobaan sederhana, peserta didik dipacu untuk mengabstraksikan sendiri pengalamannya untuk memperoleh kesimpulan. Untuk memperkuat pemahaman, dilakukan kegiatan menyimpulkan pembelajaran bersamasama dan kegiatan evaluasi sekaligus membahas jawaban evaluasi.

Peningkatan hasil belajar IPA peserta didik pada tema Panas dan Perpindahannya diukur dengan menggunakan teknik tes hasil belajar dengan instrumen lembar soal evaluasi. Teknik 
pengumpulan data hasil belajar peserta didik diterapkan pada setiap pertemuan setelah dilakukan proses pembelajaran. Aspek yang diukur yaitu aspek kognitif atau pengetahuan yang terdiri dari empat ranah yaitu mengingat (C1), memahami (C2), mengaplikasi (C3), dan menganalisis (C4) yang diukur berdasarkan hasil evaluasi setelah mengikuti pembelajaran dengan penggunaan model Experiential Learning pada materi panas dan perpindahannya.

Berdasarkan hasil evaluasi peserta didik, diketahui bahwa pada ranah kognitif mengingat dan memahami telah dapat dikuasai dengan baik oleh peserta didik. Selain itu, peserta didik juga telah mampu menuliskan jawaban uraian pada jenjang kognitif analisis dengan kalimat yang jelas, lengkap, dan efektif. Namun, sebagian peserta didik masih terkecoh dengan opsi jawaban soal pilihan ganda pada jenjang kognitif aplikasi.

Penggunaan model Experiential Learning dalam pembelajaran IPA dapat meningkatkan hasil belajar peserta didik di kelas V SD Negeri 3 Waluyo secara signifikan. Hal ini sesuai dengan hasil penelitian yang dilakukan oleh Munif dan Mosik [9] yang membuktikan bahwa model Experiential Learning dapat meningkatkan hasil belajar IPA di kelas V SD secara signifikan. Pada hasil Penilaian Tengah Semester (PTS) semester ganjil tahun ajaran 2018/2019 terdapat 14 dari 27 peserta didik yang belum mencapai KKM dengan persentase ketuntasan hasil belajar hanya $48 \%$. Setelah dilakukan tindakan, persentase ketuntasan hasil belajar pada siklus I meningkat menjadi $63 \%$ pada pertemuan pertama, $81 \%$ pada pertemuan kedua, dan $85 \%$ pada pertemuan ketiga. Pada siklus II terjadi peningkatan kembali pada pertemuan kedua menjadi 93\% dan pada pertemuan ketiga mencapai $100 \%$. Berdasarkan hasil di atas, dapat diketahui bahwa pada siklus I pertemuan pertama dan kedua belum mencapai indikator kinerja penelitian yang ditetapkan. Hasil belajar pada siklus I pertemuan ketiga telah mencapai indikator kinerja penelitian dan terus meningkat pada siklus II. Pada siklus II pertemuan ketiga, ketuntasan hasil belajar IPA peserta didik telah mencapai $100 \%$ dengan KKM 75 sehingga pelaksanaan tindakan dapat dihentikan. Berdasarkan pembahasan hasil di atas tentang hasil belajar peserta didik yang didukung penelitian yang telah dilakukan, dapat diambil kesimpulan bahwa penggunaan model Experiential Learning dapat meningkatkan hasil belajar IPA pada tema Panas dan Perpindahannya di kelas V SDN 3 Waluyo tahun ajaran 2018/2019.

Berdasarkan hasil observasi langkah model Experiential Learning, ditemukan beberapa kendala dalam pembelajaran yaitu (a) peserta didik kurang aktif saat menjawab pertanyaan pancingan guru karena merasa malu dan takut salah jika menjawab pertanyaan; (b) terdapat peserta didik yang sulit memahami materi pelajaran, karena belum mampu menyesuaikan diri dengan model Experiential Learning dan kurangnya bimbingan guru kepada peserta didik yang mengalami kesulitan; (c) banyak peserta didik yang tidak mau maju untuk menyampaikan hasil diskusi; (d) beberapa peserta didik dalam satu kelompok tidak fokus memperhatikan penjelasan saat pembelajaran berlangsung karena posisi duduk kelompok yang berada di pojok belakang sehingga jauh dari pengawasan guru; dan (e) peserta didik masih kesulitan saat menyampaikan pendapat menggunakan bahasa yang jelas karena masih kurang percaya diri serta takut pendapatnya ternyata salah. Kendala yang ditemukan sesuai dengan pendapat Hosnan [5] yang mengemukakan bahwa model ini sangat bergantung pada kemampuan guru dalam merencanakan pengalaman belajar yang terbuka serta guru harus mampu memberikan rangsangan dan motivasi yang lebih kepada peserta didik.

Berdasarkan kendala yang ditemui saat pembelajaran, solusi yang telah diterapkan guru yaitu: (a) memberikan penghargaan bagi peserta didik yang aktif menjawab pertanyaan; (b) memberikan bimbingan yang lebih bagi peserta didik yang mengalami kesulitan memahami materi; (c) menunjuk semua anggota kelompok untuk maju mempresentasikan hasil diskusi namun menyampaikan secara individu di depan kelas; (d) memberikan lebih banyak pengawasan, peringatan, serta tugas khusus bagi kelompok yang tidak memperhatikan; dan (e) memberikan motivasi, membimbing peserta didik saat menyampaikan pendapat, serta memberikan penghargaan bagi peserta didik yang berani menyampaikan pendapat menggunakan bahasa yang jelas dan runtut.

\section{KESIMPULAN}

Berdasarkan hasil penelitian dapat Experiential Learning dengan langkah-langkah Concrete Experience, Reflective Observation, Abstract Conceptualization, serta Active Experimentation dapat meningkatkan hasil belajar IPA pada tema Panas dan Perpindahannya di kelas V SDN 3 Waluyo tahun ajaran 2018/2019 yang dibuktikan dengan persentase ketuntasan hasil belajar pada siklus I sebesar 76,33\% menjadi $92,63 \%$ pada siklus II. Kendala yang ditemui yaitu: (1) peserta didik kurang aktif menjawab pertanyaan, (2) peserta didik sulit memahami materi, (3) peserta didik malu mempresentasikan hasil diskusi, (4) peserta didik tidak fokus dalam pembelajaran, dan (5) peserta didik kesulitan menyampaikan pendapat dengan jelas. Adapun solusi yang diterapkan yaitu: (1) memberikan penghargaan bagi peserta didik yang aktif, (2) memberikan bimbingan yang lebih, (3) semua anggota kelompok maju mempresentasikan hasil diskusi, (4) memberikan pengawasan yang lebih, 
(5) membimbing saat penyampaian pendapat. Hasil penelitian ini sangat penting untuk direkomendasikan kepada guru kelas sebagai upaya perbaikan dan peningkatan kualitas proses dan hasil belajar. Tindak lanjut yang dapat dilakukan oleh guru yaitu mensosialisasikan model Experiential Learning kepada guru kelas lain dalam kegiatan $\mathrm{KKG}$, diklat atau kegiatan pengembangan profesionalitas guru lainnya.

\section{DAFTAR PUSTAKA}

[1] Susanto, A. (2013). Teori Belajar dan Pembelajaran di Sekolah Dasar. Jakarta: Prenada Media Group

[2] Ningsyih, S., Junaidi, E., \& Al Idrus, S. W. (2016). Pengaruh Pembelajaran Praktikum Berbasis Inkuiri Terbimbing Terhadap Kemampuan Berpikir Kritis Dan Hasil Belajar Kimia Siswa. Jurnal Pijar Mipa, 11(1).

[3] Bartle, E (2015). Experiential Learning: an Overview. A Discussion Paper for Professor Joanne Eright, Deputy Vice-Chancellor (Academic) for the Vice-Chancellor's Retreat, March $23^{\text {rd }} \& 24^{\text {th }}: 2-8$.

[4] Fathurrohman, M. (2017). Model-model Pembelajaran Inovatif. Yogyakarta: Ar-Ruzz Media.

[5] Hosnan. (2014). Pendekatan Saintifik dan Kontekstual dalam Pembelajaran Abad 21: Kunci Sukses Implementasi Kurikulum 2013. Bogor: Ghalia Indonesia.

[6] Jannati, E.D. (2016). Model Pembelajaran Experiential Kolb untuk Meningkatkan Kemampuan Menjelaskan Fenomena Fisis pada Konsep Optik. Jurnal Grafity, 2(2): 143155.

[7] Kuswandari, D., Suhartono, \& Salimi. (2017). Penerapan Model Experiential Learning untuk Meningkatkan Keterampilan Menulis Karangan pada Siswa Kelas IV SD Negeri 4 Kuwayuhan. Kalam Cendekia, 2(1): 202-206.

[8] Leonard. (2018). Task and forced instructional strategy: instructional strategy based on character and culture of Indonesia nation. Formatif: Jurnal Ilmiah Pendidikan MIPA, 8(1): 51-56.

[9] Munif, I.R.S \& Mosik. (2009). Penerapan Metode Experiential Learning pada Pembelajaran IPA untuk Meningkatkan Hasil Belajar Siswa di Sekolah Dasar. Jurnal Pendidikan Fisika Indonesia, 5(1): 79-82.

[10] Nurhasanah, S., Malik, \& Mulhayatiah. (2017). Penerapan Model Experiential Learning untuk Meningkatkan Keterampilan Berpikir Kritis Siswa. Jurnal Wahana Pendidikan Fisika, 2(2): 58-62.

[11] Rodliyah, I., Saraswati, \& Sa'adah. (2018). Implementasi Model Experiential Learning pada Meteri Kelipatan Persekutuan Terkecil dan Faktor Persekutuan Terbesar Kelas IV. Jurnal Gantang, 3(2): 143-151.

[12] Samatowa, U. (2016). Pembelajaran IPA di Sekolah Dasar. Jakarta: Indeks.

[13] Wildan, H. (2009). Pengembangan Pembelajaran Sains Berorientasi Iman dan Taqwa. Jurnal Pijar Mipa, 4(1). 